ТРАДИЦІЙНІ ТА ІННОВАЦІЙНІ ПОСЛУГИ НА РИНКУ БАНКІВСЬКИХ ПРОДУКТІВ УКРАЇНИ

\title{
TRADITIONAL AND MODERN PRODUCTS ON THE MARKET BANKING SERVICES OF UKRAINE
}

\section{УДК 336.7}

https://doi.org/10.32843/infrastruct42-50

\section{Ганзюк С.М.}

к.е.н., доцент

доцент кафедри фрінансів та обліку Дніпровський державний технічний університет

Шаровський М.ю.

магістр

Дніпровський державний технічний університет

\section{Hanziuk Svitlana}

Dniprovskyi State Technical University Sharovskyi Mykola

Dniprovsky State Technical University of Kamianske

\begin{abstract}
y статmі розглянуто сутність дефрініціі «банківська послуга», охарактеризовано основні види традиційних та інноваційних банківських послуг. Виділено найпоширеніші інноваційні продукти українських банків. Згруповано основні зовнішні стимулятори та дестимулятори розвитку вітчизня ного ринку банківських послуг. Проаналізовано структурну зміну банківської системи України, зміну обсягів доходів, витрат та фрінансових результатів діяльності українських банків за останні п'ять років. Установлено, що найбільш прибутковими послугами банків залишаються традичійні кредитні та розрахунково-касові операції, найбільш поши реним сучасним продуктом - Інтернет банкінг. Проаналізовано кількість та обсяг безготівкових операцій в Україні. Виділено найбільш технологічно прогресивних вітчизняних учасників на ринку банківських послуг. Запропоновано рекомендації щодо подальшого розвитку та розширення спектру послуг на ринку банківських продуктів України.

Ключові слова: традиційні банківські послуги, інноваційні послуги, ринок банківських послуг, кредитні операції, розрахунково-касове обслуговування, Інтернетбанкінг, відеобанкінг, еквайринг, лізингові операції, безготівкові розрахунки.
\end{abstract}

В статье рассмотрена сущность дефи ниции «банковская услуга», охаракте- ризованы основные виды традиционных и инновационных банковских услуг. Выделены наиболее распространенные инновационные продукты украинских банков. Сгруппированы основные внешние стиму ляторы и дестимуляторы развития отечественного рынка банковских услуг. Проанализированы структурное изменение банковской системы Украины, изменение объемов доходов, расходов и фринансовых результатов деятельности украинских банков за последние пять лет. Установ лено, что наиболее прибыльными услугами банков остаются традиционные кредит ные и расчетно-кассовые операции, наиболее распространенным современным продуктом - Интернет-банкинг. Проанализированы количество и объем безналичных операций в Украине. Выделены наиболее технологически прогрессивные отечественные участники на рынке банковских услуг. Предложены рекомендации по дальнейшему развитию и расширению спектра услуг на рынке банковских продуктов Украины.

Ключевые слова: традиционные банковские услуги, инновационные услуги, рынок банковских услуг, кредитные операции, расчетно-кассовое обслуживание, Интернетбанкинг, видеобанкинг, эквайринг, лизинговые операции, безналичные расчеты.

In the article describes the essence of the definition of "banking service", describes the main types of traditional and innovative banking services. The most common innovative products of Ukrainian banks are highlighted, including: internet banking, payments via mobile phone, e-mail, merchant acquiring, factoring, forfaiting, self-service centers. The main external stimuli (development of banking infrastructure and information technologies, support by the state of banks in the implementation of various joint projects) and stimulators (political and economic factors, uneven conditions of competition, mistrust of banks) of the development of the domestic market of banking services are grouped. The structural changes of the Ukrainian banking system, changes in the volume of income, expenses and financial results of Ukrainian banks' activity over the last five years are analyzed. Despite the rapid reduction in the number of structural units and the difficulties caused by the development stimulators, the banking system of Ukraine has developed more dynamically in recent years than other segments of the economy and has received positive financial results in the last two years. The Ukrainian banking services market is almost absent from relatively stable sources of supply and growing demand from legal entities and individuals to meet interest rates that guarantee an adequate margin. It is established that the most profitable services of banks are the traditional credit and settlement and cash transactions, the most common modern product Internet banking. The number and volume of non-cash transactions in Ukraine is analyzed. The most technologically progressive domestic participants in the banking services market are highlighted. Recommendations are offered on the further development and expansion of the range of services in the banking products market of Ukraine, in particular, to focus their efforts on the development of consulting, information, trust, guarantee services and auxiliary operations, which are interrelated with the provision of activities of consumers of banking ambassadors, as well as constantly improve traditional banking products. Key words: traditional banking services, innovative services, banking services market, credit operations, settlement and cash services, Internet banking, video banking, acquiring, leasing operations, non-cash payments.

Постановка проблеми. Незважаючи на значне скорочення останнім часом, на вітчизняному ринку банківських послуг фрункціонують багато установ, що конкурують між собою за залучення нових клієнтів і збереження стабільної клієнтської бази. Використання в організації банківського обслуговування не тільки традиційних, а й сучасних інноваційних продуктів, безперечно, забезпечуватиме поліпшення якості послуг, зростання кількості нових клієнтів та, відповідно, доходів фрінансово-кредитних установ. Банківські інновації $€$ життєво важливими для ефективного функціонування і розвитку діяльності банку, тому дослідження питання, пов'язаного з аналізом існуючих та сучасних інноваційних продуктів вітчизняних банків, є актуальним. Особливої важливості розвиток наукових досліджень із даної тематики набуває в умовах фрінансово-економічної нестабільності в країні через запровадження карантинних дій та тривалого конорлікту на Сході, коли провідні фрінансові установи зазнають значного відпливу фрінансових ресурсів.

Аналіз останніх досліджень і публікацій. Дослідження інноваційних та традиційно існуючих банківських послуг привертають увагу багатьох вітчизняних і зарубіжних науковців та практиків, що пояснюється розширенням спектру послуг і модернізацією усієї банківської системи. Серед 
вітчизняних авторів слід виділити М.Д. Алєксєєнка, О.А. Брегеду, О.В. Васюренка, В.В. Вітлінського, Д.Д. Гладких, У.М. Гулієва, О.В. Дзюблюк, Ю.А. Зарубу, О.А. Кириченка, О.М. Олійник, Л.О. Примостка, В.І. Павлюк та ін. Віддаючи належне вагомим напрацюванням у даній сорері, варто зазначити, що дослідження стану розвитку вітчизняного ринку банківських продуктів, їх інноваційності потребує постійного моніторингу та аналізу.

Постановка завдання. Метою дослідження $\epsilon$ розгляд сутності та основних видів традиційних та інноваційних продуктів на ринку банківських послуг; групування стимуляторів та дестимуляторів розвитку банківської системи України; аналіз стану та перспектив розвитку вітчизняного ринку банківських послуг.

Виклад основного матеріалу дослідження. Ринок банківських послуг в останні часи переживає складні зміни у зв'язку з макроекономічними умовами та кризовими явищами, тому українські банки повинні прикладати великих зусиль для зберігання довіри існуючих клієнтів та залучення нових.

У науковій літературі виокремлено концепцію, відповідно до якої до складу банківських послуг входить окремий, порівняно вузький сегмент діяльності банку. При цьому послугою вважається діяльність банківської установи, яка безпосередньо не пов'язана з активними і пасивними операціями. Існує думка, що банківські послуги - це посередницькі операції банків, головною ознакою яких $є$ отримання банком доходу у вигляді комісійних за обслуговування [1]. Н.М. Перепечай поняття «банківська послуга» визначає як результат комплексної діяльності банку, який становить економічні блага для задоволення певних потреб людини під час проведення банківських операцій [2]. Ми погоджуємося 3 думкою В.А. Шпильового, який дефрініцію «банківська послуга» визначає як комплексний результат діяльності банківської установи щодо максимального задоволення зростаючих із часом вимог клієнтів під час проведення банківських операцій або із залучення тимчасово вільних ресурсів, що спрямовані на одержання прибутку [3, с. 28].

Зазначимо, що у банківництві складно виділити чіткі ознаки інноваційності послуг, оскільки підґрунтям більшості інноваційних послуг $є$ традиційні. Своєю чергою, інноваційні послуги є для окремих комерційних банків звичайними та такими, що не виділяють їх в окремі новітні. Залежно від впливу на поведінку споживачів для тих комерційних банків, які використовують новітні послуги, існує в науковій літературі поділ послуг на адаптивні, функціональні та фрундаментальні інновації. Зокрема, адаптивні інновації мають на меті мінімізацію змін у продукті чи послузі і не вимагають ніяких змін у поводженні споживачів; функціональні інновації припускають збереження фрункції послуги, але характер реалізації фрункції зміню- ється; фрундаментальні мають на меті реалізацію нової концепції чи ідеї, у результаті якої виникають нові фрункціональні можливості [4].

У банківській практиці застосовуються найпоширеніший поділ послуг на традиційні (депозитні, кредитні, розрахунково-касові та інші послуги) та нетрадиційні (раніше не належали до характерних банківських послуг, з'явилися відносно нещодавно).

Серед нетрадиційних послуг комерційних банків, що активно використовуються в Україні, слід виділити:

- Інтернет-банкінг, телефонний банкінг, відеобанкінг;

- безкарткові розрахунки через мобільний телефон;

- режим роботи «24/7»;

- електронна решта: решта в копійках переводиться на рахунок чи поповнює мобільний телефон клієнта;

- торговий еквайринг: дає змогу торгово-сервісним підприємствам приймати в оплату за свої товари та послуги банківські платіжні картки;

- фракторинг: різновид торговельно-комерційної операції, яка поєднується 3 кредитуванням його дебіторської заборгованості;

- фрорфейтинг: фрорма коротко- і середньострокового кредитування зовнішньоекономічних операцій шляхом купівлі комерційним банком векселів, акцептованих імпортером, тобто експортер переуступає банку свої вимоги до покупця;

- центри самообслуговування;

- лізингові операції: оренда машин, устаткування, транспортних засобів, споруд виробничого призначення;

- кеш-менеджмент -- комплекс послуг, які пропонують комерційні банки, що дає змогу клієнтам зменшити витрати й ефективно управляти своїми фрінансовими потоками. Як правило, включає кілька складників: управління банківськими рахунками, ліквідністю, розрахунково-касове обслуговування, управління процентною ставкою, електронний банкінг і різні інформаційні сервіси.

Зазначимо, діяльність українських банків знаходиться в постійній взаємодії 3 навколишнім середовищем, яке впливає на диверсиорікацію послуг банків. На рис. 1 згруповано найбільш істотні чинники, що впливають на розвиток українського ринку банківських послуг. Усі діючі чинники взаємопов'язані та діють іноді по-різному на стан і тенденції розвитку ринку банківських продуктів.

Внутрішнє середовище банку являє собою частину загального середовища, яка знаходиться в межах окремої установи і здійснює безпосередній вплив на фрункціонування банку. Зрозуміло, що внутрішні чинники життєздатності банківських послуг зумовлені загальним потенціалом окремого банку. Отже, на розвиток банківських послуг 


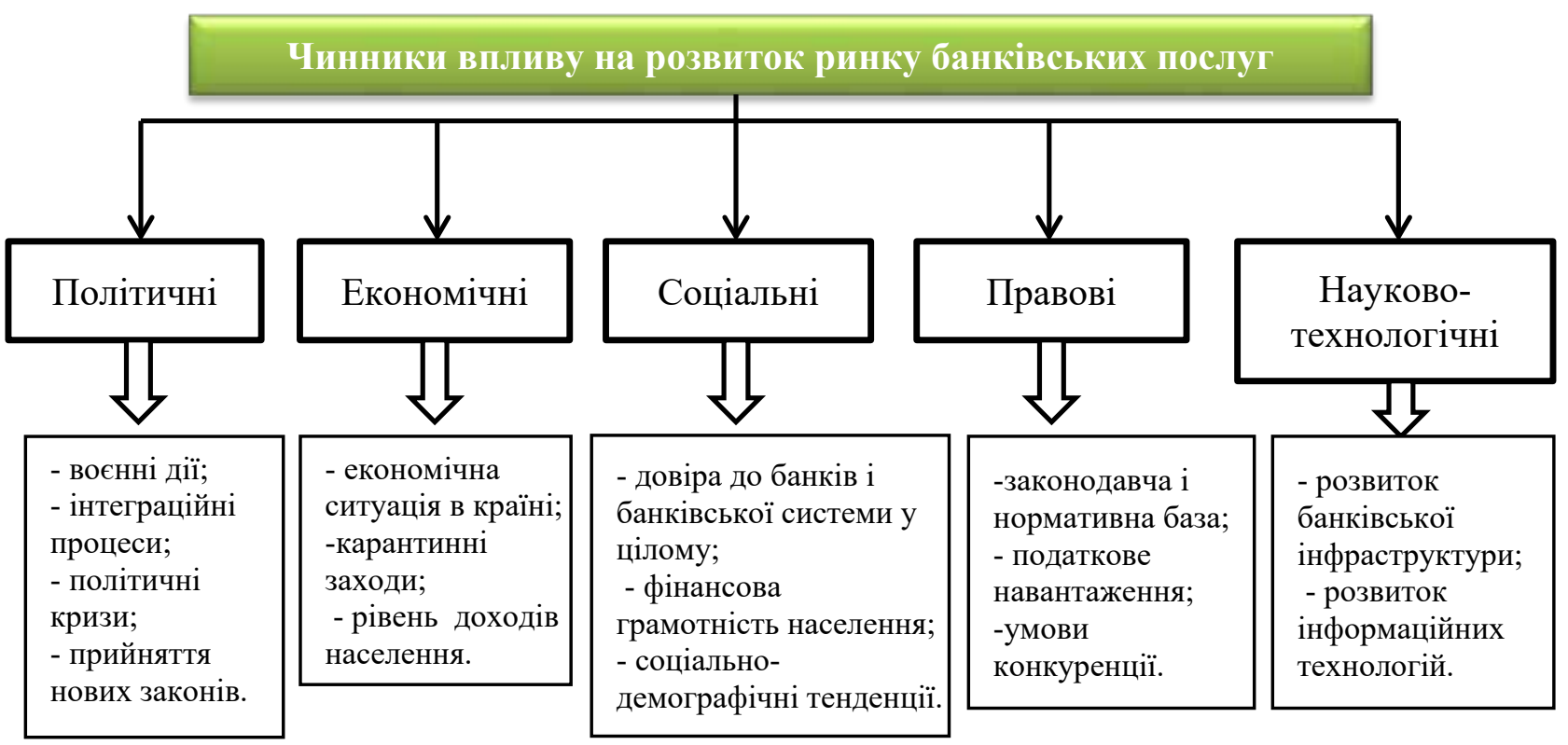

Рис. 1. Зовнішні чинники впливу на ринок банківських послуг в Україні

впливає низка чинників та умов, одні з яких стимулюють (розвиток банківської інфрраструктури та інформаційних технологій; підтримка 3 боку держави банків у рамках реалізації різних спільних проєктів, страхування вкладів фрізичних осіб), а інші стримують їх розвиток (політико-економічні чинники, нерівномірні умови конкуренції, недовіра населення до банків).

Банківська система України, незважаючи на стрімке скорочення кількості структурних одиниць (табл. 1) та труднощі, зумовлені негативними чинниками впливу, розглянутими раніше, протягом останніх років розвивалася динамічніше, ніж інші сегменти економіки, та отримувала позитивний фрінансовий результат діяльності в остання два роки (табл. 2).

За період 2015-2019 рр. кількість банків скоротилася зі 117 до 75 од., у тому числі з іноземним капіталом - до 35 банків, до 23 банків - зі 100\%-м інозем- ним капіталом станом на 01.01.2020 [5]. Причини, за якими банки визнавалися неплатоспроможними, були різними. Більшість ліквідованих банків не впоралися $з$ викликами, що постали перед банківським сектором у кризових умовах фрункціонування, не змогли адаптувати структуру своїх активів та втримати їх якість на належному рівні.

За п'ять останніх років у цілому зростання доходів становило 18,5\% за рахунок зростання процентних доходів на 12,4\% та комісійних доходів на рекордні 54,2\% (табл. 2). Отже, за рахунок зростання обсягу традиційних кредитних та розрахунково-касових операцій банківські установи отримали зростання прибутку за 2015-2019 рр. на 110,6\%, попри неймовірно збиткові 2014-2017 рр.

Разом із цим варто підкреслити, що на ринку банківських послуг майже відсутні відносно стабільні джерела постачання ресурсів, захисні бар'єри від інтервенцій нових учасників ринку,

Таблиця 1

Структурні зміни в банківській системі України за період 2015-2019 рр., од.

\begin{tabular}{|l|c|c|c|c|c|}
\hline \multicolumn{1}{|c|}{ Показники } & $\mathbf{2 0 1 5}$ & $\mathbf{2 0 1 6}$ & $\mathbf{2 0 1 7}$ & $\mathbf{2 0 1 8}$ & $\mathbf{2 0 1 9}$ \\
\hline Платоспроможні банки: & 117 & 96 & 82 & 77 & 75 \\
\hline зміна до попереднього року & -30 & -21 & -14 & -4 & -2 \\
\hline Державні & 7 & 6 & 5 & 5 & 5 \\
\hline зміна до попереднього року & 0 & -1 & -1 & 0 & 0 \\
\hline Іноземні & 25 & 25 & 23 & 21 & 23 \\
\hline зміна до попереднього року & 0 & 0 & -2 & -2 & +2 \\
\hline Приватні & 85 & 65 & 54 & 51 & 47 \\
\hline зміна до попереднього року & -30 & -20 & -11 & -2 & -4 \\
\hline Неплатоспроможні банки & 3 & 4 & 2 & 1 & - \\
\hline міна до попереднього року & -13 & 1 & -2 & 0 & -1 \\
\hline У стадії ліквідації & 64 & 84 & 95 & 99 & 18 \\
\hline зміна до попереднього року & 43 & 20 & 11 & 2 & -81 \\
\hline
\end{tabular}

Джерело: [5] 
Доходи, витрати та фінансовий результат діяльності банків України за період 2015-2019 рр., млн грн

\begin{tabular}{|l|c|c|c|c|c|c|}
\hline \multicolumn{1}{|c|}{ Показники } & $\mathbf{2 0 1 5}$ & $\mathbf{2 0 1 6}$ & $\mathbf{2 0 1 7}$ & $\mathbf{2 0 1 8}$ & $\mathbf{2 0 1 9}$ & $\begin{array}{c}\text { Відн. відх. } \\
\mathbf{2 0 1 9 / 2 0 1 5} \text { рр.,\% }\end{array}$ \\
\hline Доходи, у т.ч. & 199193 & 190691 & 178054 & 204459 & 244402 & $+18,5 \%$ \\
\hline процентні доходи & 135145 & 135807 & 124009 & 140859 & 154309 & $+12,4 \%$ \\
\hline комісійні доходи & 28414 & 31362 & 37138 & 50968 & 62062 & $+54,25 \%$ \\
\hline Витрати, у т.ч. & 265793 & 350078 & 204545 & 182734 & 184768 & $-30,5 \%$ \\
\hline процентні витрати & 96079 & 91638 & 70971 & 67759 & 74014 & $-22,9 \%$ \\
\hline комісійні витрати & 5846 & 7182 & 9650 & 13158 & 18089 & $67,7 \%$ \\
\hline відрахування в резерви & 114541 & 198310 & 49206 & 23705 & 2106 & $-98,1 \%$ \\
\hline Чистий прибуток (збиток) & -66600 & -159388 & -26491 & 21726 & 59634 & $+110,6 \%$ \\
\hline
\end{tabular}

Джерело: [5]

зростаючий попит із боку юридичних та фрізичних осіб, який би відповідав відсотковим ставкам, що гарантують адекватну маржу [6]. Конкуренція в банківській галузі та економічна криза вимагають від фрінансових установ упровадження найсучасніших видів послуг, і це питання для багатьох банків $€$ питанням не тільки лідерства, а й виживання.

Українська практика успішно поєднує у собі багато варіантів традиційного та сучасного дистанційного банківського обслуговування, проте базовою та найбільш поширеною сучасною послугою вважається Інтернет-банкінг, яку в Україні надають багато фрінансово-кредитних установ. Найбільш активними та технологічно провідними учасниками ринку є: «ПриватБанк», «АльфаБанк», «VTB Банк», «ПУМБ», «Райффрайзен Банк Аваль», «Укрсиббанк», «Укрсоцбанк» [7]. Лідером за впровадженням Інтернет-технологій в Україні, безперечно, $\epsilon$ «ПриватБанк», база якого давно перевищує мільйон осіб. Найважливішою перевагою Інтернетбанкінгу, на думку клієнтів, є здатність управляти поточними рахунками дистанційно, не відвідуючи відділення банку. Важливим кроком для розвитку онлайн-банкінгу стала підтримка НБУ єдиного стандарту електронної дистанційної ідентифрікації клієнтів BankID, який сьогодні надає можливість отримувати адміністративні послуги від держави, а в перспективі, за умови доопрацювання нормативної бази, дасть змогу отримувати всі банківські послуги без візиту до відділення банку [7].

Українці все більше розраховуються безготівково, використовуючи зручні та безпечні інструменти оплати. У 2018 р. обсяг безготівкових операцій становив майже 1,3 трлн. грн [9]. Кількість безготівкових операцій зросла майже на 33,0\% порівняно 32017 р. і становила 3,1 млрд. шт., а обсяг - на 55,4\% та досяг 1297 млрд. грн [8]. Такий позитивний тренд пов'язаний зі стабільним підвищенням попиту на безготівкові операції серед українців та популяризацією інноваційних фрінансових сервісів.

Висновки 3 проведеного дослідження. Отже, українські банки намагаються відповідати сучасним викликам світових інноваційних тенденцій за кількістю й якістю послуг для своїх клієнтів. Найбільш прибутковими послугами вітчизняних банків сьогодні залишаються традиційні кредитні та розрахунково-касові операції, найбільш поширеним сучасним продуктом - Інтернет-банкінг. Головними стимуляторами розвитку вітчизняного банківського сектору визначено вдосконалення банківської інфрраструктури та інфрормаційних технологій, підтримка з боку держави банків у рамках реалізації різних спільних проєктів; дестимулюють розвиток політико-економічні чинники та традиційна недовіра населення до фрінансово-кредитних установ. Банкам у подальшому доцільно спрямувати свої зусилля на розвиток консультаційних, інфрормаційних, трастових, гарантійних послуг та допоміжних операцій, які мають взаємозв'язок із забезпеченням діяльності споживачів банківських послуг, та постійно вдосконалювати традиційні банківські продукти. Розвиток сучасних банківських послуг значною мірою залежить від готовності та бажання самих банків змінюватися та адаптуватися відповідно до потреб своїх клієнтів та умов фрункціонування.

\section{БІБЛІОГРАФІЧНИЙ СПИСОК:}

1. Трохименко B.І. Сутність та структура сучасного ринку банківських послуг. Економіка. Проблеми економічного становлення. 2010. № 2. С. 76-81.

2. Перепечай Н.М. Перспективи розвитку ринку нетрадиційних банківських послуг. Фінанси України. 2009. № 3. С. 133-139.

3. Дзюблюк О. Ринок банківських послуг: теоретичні аспекти організації стратегії розвитку в Україні. Фінанси України. 2005. № 6. С. 41-49.

4. Сидорук І.С. Перспективи розвитку новітніх послуг комерційних банків України. Науковий блог Національного університету «Острозька академія». URL : https://naub.oa.edu.ua/2014/perspektyvyrozvytku-novitnih-posluh-komertsijnyh-bankiv-ukrajiny/ (дата звернення: 25.04.2020).

5. Наглядова статистика : офіційний сайт НБУ. URL : https:// bank.gov.ua/statistic/supervision-statist (дата звернення: 12.03.2020). 
6. Привалова І.М. Р2Р-кредитування як елемент конкуренції на ринку банківських послуг України. Регіональна бізнес-економіка та управління. 2014. № 2(42). C. 84-88.

7. Тищенко O.I. Огляд сучасних тенденцій на ринку онлайн-банкінгу в Україні. Економіка і суспільство. 2017. Вип. 13. С. 1237-1243.

8. Огляд ринку платіжних карток та платіжної інфраструктури України за 2018 рік : офріційний сайт НБУ. URL : https://bank.gov.ua/doccatalog/ document?id=88661687.

\section{REFERENCES:}

1. Trokhymenko V. (2010), Sutnist Ta Struktura Suchasnoho Rynku Bankivskykh Posluh [The essence and structure of the modern banking services market] Economy. Problems of economic formation. No 2. P. 76-81. (in Ukrainian)

2. Perepechay N. M. (2009) Perspektyvy rozvytku rynku netradytsiynykh bankivs'kykh posluh [Prospects for the development of the market of non-traditional banking services]. Finance of Ukraine. № 3. P. 133-139.

3. Dzyublyuk O. (2005) Rynok bankivs'kykh posluh: teoretychni aspekty orhanizatsiyi stratehiyi rozvytku $\mathrm{v}$ Ukrayini [Banking services market: theoretical aspects of organization of development strategy in Ukraine]. Finance of Ukraine. № 6. P. 41-49.

4. Sydoruk I.S. (2014), Perspektyvy rozvytku novitnikh posluh komertsiynykh bankiv Ukrayiny [Prospects for development of the newest services of commercial banks of Ukraine]. URL: https://naub.oa.edu.ua/2014/ perspektyvy-rozvytku-novitnih-posluh-komertsijnyhbankiv-ukrajinyl (in Ukrainian) (accessed 12.03.2020).

5. Supervisory statistics: NBU official site. URL: https://bank.gov.ua/statistic/supervision-statist (accessed 12.03.2020)

6. Pryvalova I.M. (2014), R2R kredytuvannya - yak element konkurentsiyi na rynku bankivs'kykh posluh Ukrayiny [P2P lending - as an element of competition in the banking market of Ukraine]. Regional Business Economics and Management. № 2(42). P. 84-88.

7. Tyshchenko O.I. (2017), Ohlyad suchasnykh tendentsiy na rynku onlayn-bankinhu v Ukrayini. [An overview of current trends in the online banking market in Ukraine]. Economy and society. Issue 13. P. 1237-1243.

8. Ohlyad rynku platizhnykh kartok ta platizhnoyi infrastruktury Ukrayiny za 2018 rik [Market Overview of Payment Cards and Payment Infrastructure of Ukraine for 2018 / Official Website of the National Bank of Ukraine. URL: https://bank.gov.ua/doccatalog/ document?id=8866 1687 (accessed 14.01.2020). 